\title{
Coffered slabs as a perspective type of the reinforced concrete structures
}

\author{
Anton Kibkalo ${ }^{1}$, Mikhail Volkov ${ }^{1,}$, , Anna Vodolagina $^{1}$, Vera Murgul $^{1}$ \\ ${ }^{1}$ Peter the Great Saint-Petersburg Polytechnic University, 195251 St. Petersburg, Russia
}

\begin{abstract}
The article discusses coffered slabs. In this paper considered the technology of arrangement of this slabs. Cast-in-place and precast ways of construction of coffered slab are reviewed. Cast-in-place and precast coffered slabs has been analysed in this article. Among other things construction of coffered slabs has an economical and technical advantages.
\end{abstract}

\section{Introduction}

Search of optimal types of structure is one of the motivations of science development in constructing which could save time and money and also don't give strength characteristics to its analogues.

One of the most important problems of constructing branch is reduce of building materials and weight of erected parts of building.

It is possible due to:

- applying new effective structures;

- use of prestressed elements of building;

- intensive introducing light weight concretes [1].

The introducing of effective cast-in-place structures only starts now in civil and industrial building in our country. Their introduction with no doubt will reduce cost price of erection and reconstruction of buildings. It depends of methods of design of such structures in domestic building branch that are bad developed.

\section{The effective forms of coffered slabs}

The effective forms of slabs are applied in many European countries in the construction industry, to reduce the weight of slabs constructed of heavy cast-in-place concrete slab.

Single-span reinforced concrete slabs with a solid cross section is the most economical to the length of span to $4,5 \mathrm{~m}$. The span can be increased due to supporting the plate on the contour. In this case, it is possible to overlap a large area. In order to reduce consumption of concrete in the construction of floors, and consequently reducing loads on the supporting structures and foundations, it is advisable to use a cast-in-place ribbed ceiling [2]. floor.

Coffered slab (Fig. 1) is a kind of ribbed slab, it is also called waffle reinforced concrete

* Corresponding author: w2olf@mail.ru 


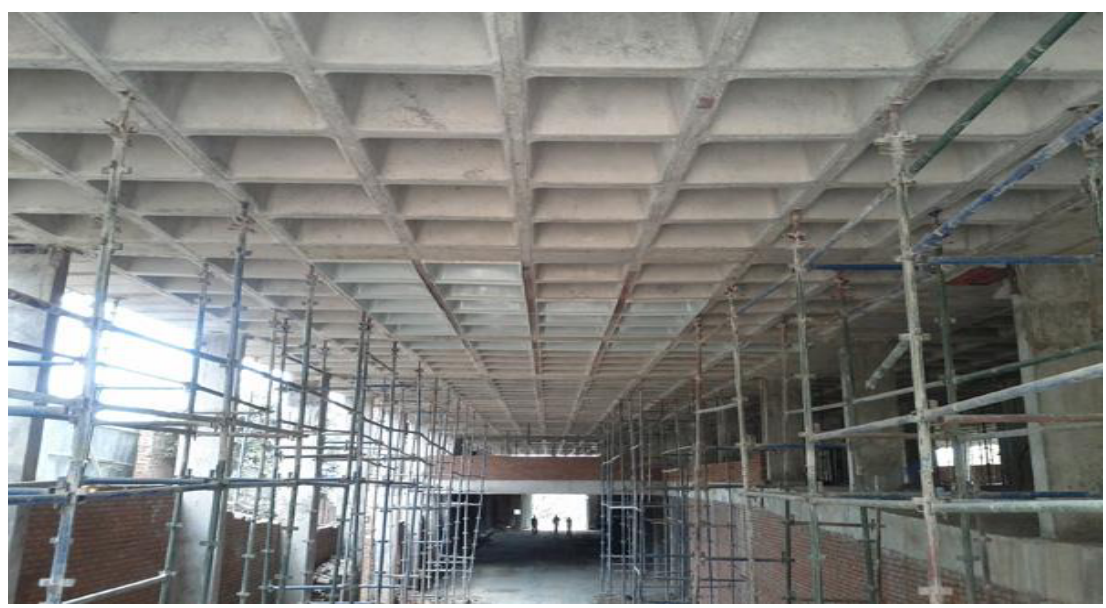

Fig. 1. Coffered slab.[3]

Coffered slab is a ribbed structure with reinforced ribs in the lower zone which have mutually perpendicular arrangement. In comparing with plate slab or cast-in-place slab with profiled sheet formwork, application of cast-in-place ribbed slab reduces the consumption of concrete for the construction of floors and vertical load bearing walls, foundations of buildings. Hence there is a reduction of costs for its construction. There is a reduction of its own weight of overlap - from $40 \%$ to $60 \%$, while rigidity of the slab is increased, which allows to arrange large spans without intermediate supports devices. The resulting thickness of the slab is much less flat.

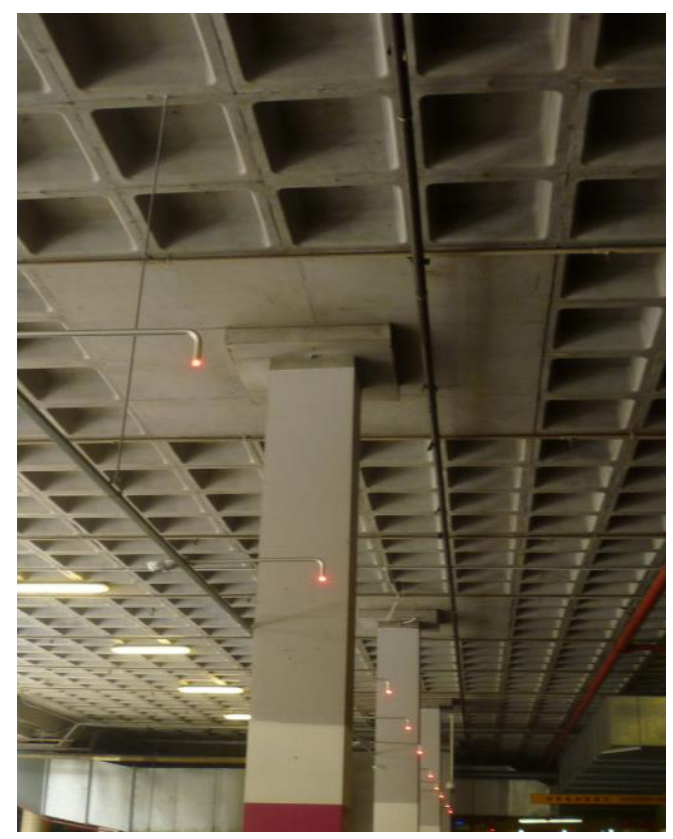

Fig. 2. Coffered slab in parking construction.[4]

Coffered slab consist of slabs supported on a contour of a system mutually perpendicular beams. Slabs have a rigid conjugation with beams and joint bearing on walls. 
The optimal side ratio for rooms with coffered ceilings in the range $1-1.5$. Beams can be placed either perpendicular or at an angle of $45^{\circ}$ (a rare variant) to the sides of the overlapped areas. The normalized height of the beams in both directions should be the same and not less than $1 / 20$ of the span. The thickness of the plates overlap coffered is $6-7 \mathrm{~cm}$, the thickness of the ribs varies from 10 to $20 \mathrm{~cm}$. [5, 6]

For devices coffered cast-in-place slab are used formwork modular system consisting of telescopic racks, lathing which is located with the size of formwork. The most common type of coffered self-supporting formwork system type «Skydome» (Fig. 3). All elements of the formwork is prefabricated; system does not require reinforcement or special protective devices. Boxes, which form voids between slabs, laid on the lathing. They have not a high adhesion to concrete and can be easily removed after a set of concrete required strength. [6]

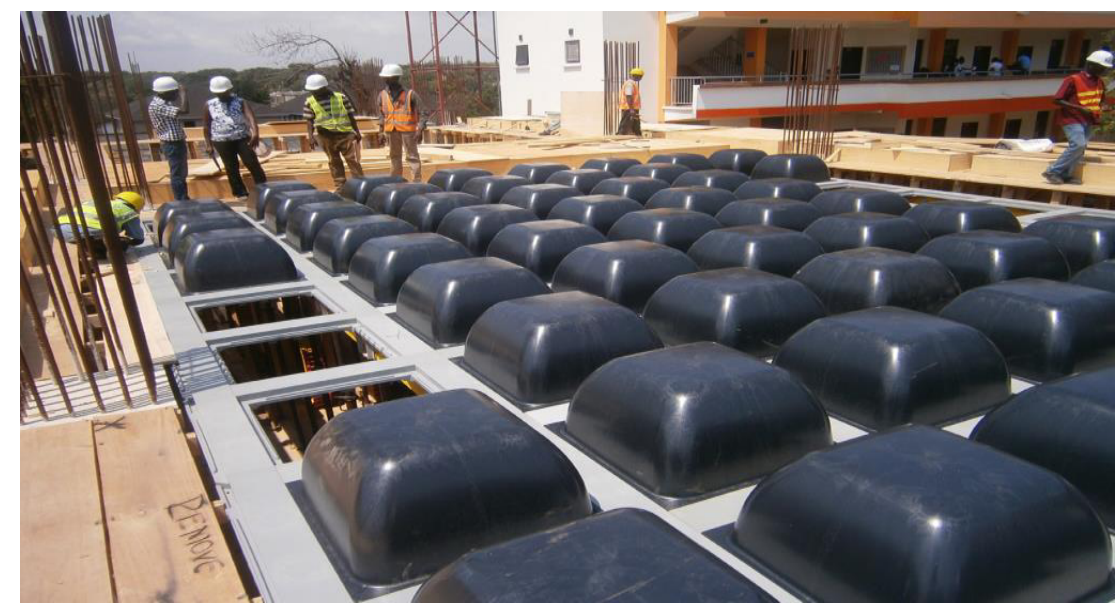

Fig. 3. Coffered formwork system type «Skydome».[7]

Comparison of the technical and economic indicators of a cast-in-place coffered floor and solid cast-in-place slab under the same loads and boundary conditions shows that by reducing the weight of the first possible to increase the thickness of the floor up to $40 \%$ while saving $15 \%$ of the concrete by removing it from the stretched bottom zone. [8]

Table 1. Technical and economic indicators overlap with the device span $12 \mathrm{~m}$, and short-term regulatory load $6 \mathrm{kN} / \mathrm{m}^{2}$.

\begin{tabular}{|c|c|c|c|}
\hline Characteristic & Thickness, cm & $\begin{array}{c}\text { Concrete } \\
\text { consumption, } \mathbf{~ m}^{\mathbf{2}}\end{array}$ & $\begin{array}{c}\text { Consumption of the } \\
\text { working } \\
\text { reinforcement, kg / } \\
\text { sq.m. }\end{array}$ \\
\hline Solid cast-in-place & 25.0 & 0.25 & 63.84 \\
\hline $\begin{array}{c}\text { Coffered cast-in- } \\
\text { place }\end{array}$ & 46.0 & 0.19 & 24.2 \\
\hline Cost of materials, \% & - & 24 & 62.1 \\
\hline
\end{tabular}

\section{Types of manufacturing coffered}

By way of manufacturing coffered floors are divided into cast-in-place and precastmonolithic. Precast-monolithic coffered floor includes prefabricated hollow concrete blocks the size from $0.2 \times 0.2 \times 0.6$ to $0.3 \times 0.3 \times 0.8 \mathrm{~m}$ to $\mathrm{m}$ and in situ concrete. The blocks form geometric shape are closed on all sides. The layer thickness of the monolithic concrete 
under blocks $-5-6 \mathrm{~cm}$. [9] Concrete blocks act as permanent formwork, they are left in the ceiling. Thus cast-in-place concrete forms vertical ribs in the tension zone and a solid floor in the compressed zone of overlap. In the area under supports (the intersection with columns) structure is arranged as a continuous cast-in-place slab. Reinforcing mesh is placed on top of blocks and the ends of reinforcing bars are set on the blocks in the area of solid cast-in-place plate. (Figure 4).

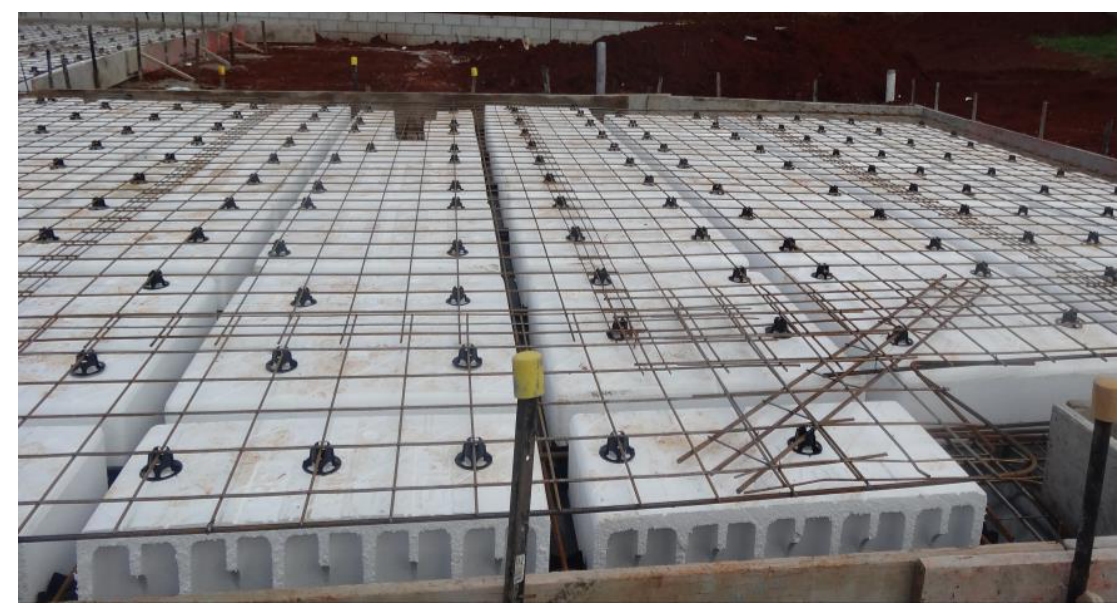

Fig. 4. Precast-monolithic coffered floor.[10]

In the manufacture of concrete blocks with a wall thickness of $2 \mathrm{~cm}$ is required at least $62-65 \%$ of the concrete mix than solid block similar size. Frame buildings with cast-inplace columns and precast-monolithic coffered floors much lighter, compared to the like of cast-in-place columns and solid monolithic slabs.

In the calculation of technical and economic parameters that characterize the consumption of the materials to device solid cast-in-place and precast-monolithic coffered ceilings it concludes that for the same consumption of concrete on the slab length of $6 \mathrm{~m}$, and the same regulatory burden savings of the working reinforcement is about $48 \%$ (Table. 2). [11-16]

Table 2. Technical and economic indicators overlap with the device span $6 \mathrm{~m}$, width $1.2 \mathrm{~m}$, and short-term regulatory load $6 \mathrm{kN} / \mathrm{m}^{2}$.

\begin{tabular}{|c|c|c|c|}
\hline Characteristic & Thicknes, cm & $\begin{array}{c}\text { Concrete } \\
\text { consumption, } \mathbf{~ m}^{2}\end{array}$ & $\begin{array}{c}\text { Consumption of the } \\
\text { working reinforcement, } \\
\mathbf{k g} .\end{array}$ \\
\hline Solid cast-in-place & 16.0 & 1.15 & 45.15 \\
\hline $\begin{array}{c}\text { Coffered precast-monolithic } \\
\text { with concrete blocks }\end{array}$ & 25.0 & 1.15 & 28.8 \\
\hline Cost of materials, \% & - & 0.0 & 48.7 \\
\hline
\end{tabular}

\section{Conclusion}

Therefore, we can conclude that the use of cast-in-place coffered slabs and precastmonolithic slabs allows to:

- to reduce the construction time by eliminating the need for installation of additional columns and foundations;

- reduce the total thickness of the floor compared to the beam structures;

- significantly reduce the consumption of material compared with a solid 
monolithic slabs;

- use open space for free layout.

\section{References}

1. I. S. Loskutov, D. A. Glotov, (2015) Information on: http://gbk.ru/concrete/ simulation /ing_fea/kessons_sim/kessons_sim.php

2. A.N. Malakova, $\bar{V}$ estnik MGSU 1, 79-86 (2013)

3. Information on http://www.rdconsultantsmw.com/?p=93

4. Information on https://www.flickr.com/photos86792135/@N0410784419463/ inphotostream

5. P.F. Vakhnenko, Calculation and design of parts of residential and public buildings (Designer directory, Kiev, 1987)

6. Manual for the design of concrete and reinforced concrete structures of heavy concrete without prestressing reinforcement (to set of rules 52-101-2003) (CNIIPromzdanii, Moscow, 2005)

7. Information on http://www.calizausa.com/en/products/slabs/skydome

8. Information on http://www.progressbuild.ru/?page_id=159

9. SP 52-101-2003. Concrete and reinforced concrete constructions without prestressing reinforcement (Moscow, 2005)

10. Information on http://forums.justcommodores.com.au/general/248098-waffle-slab.html

11. Information on http://gbk.ru/concrete/simulation/ing_fea/kessons_sim/ kessons_sim.php

12. A. Kibkalo, M. Lebedeva, M. Volkov, MATEC Web of Conferences 53, 01051 (2016)

13. S. Ognjenovic, T. Sazonova, R. Ristov, I. Nedevska, A. Kibkalo, MATEC Web of Conferences 73, 07002 (2016)

14. V. Murgul, Procedia Engineering 117,813-823 (2015)

15. V. Korsun, N. Vatin, A. Franchi, A. Korsun, P. Crespi, Mashtaler S. Procedia Engineering 117, 975-984 (2015).

16. V. Pukhkal, M. Tanić, N. Vatin, V. Murgul, Procedia Engineering 117, 864-869 (2015) 